\title{
PENGERTIAN GUGATAN DAN BENTUK GUGATAN DAN TUNTUTAN DI PENGADILAN TATA USAHA NEGARA
}

\author{
PRIMA GUNADHARMA \\ primagunadharma54@gmail.com \\ 2010003600112 \\ UNIVERSITAS EKASAKTI PADANG
}

\section{A. PENDAHULUAN}

Negara Indonesia merupakan negara hukum. Dalam Pasal 1 ayat (3) UndangUndang Dasar 1945 Amandemen ke-4 disebutkan bahwa : "Negara Indonesia adalah negara hukum". Salah satu ciri Negara hukum ialah adanya perlindungan hukum terhadap hak asasi manusia termasuk perlindungan hukum terhadap warga negara dari tindakan sewenang-wenang penguasa. Dalam kehidupan berbangsa dan bernegara, selalu terjadi interaksi hubungan antara pejabat Negara dan masyarakat. Hubungan interaksi tersebut kebanyakan biasanya terjadi karena adanya tugas-tugas pemerintahan dan pembangunan yang dilakukan oleh pejabat negara dalam rangka meningkatkan kesejahteraan masyarakat. Hubungan interaksi kebanyakan biasanya terjadi karena adanya tugas-tugas pemerintahan dan pembangunan yang dilakukan oleh pejabat negara dalam rangka meningkatkan kesejahteraan masyarakat. Hubungan antara pejabat administrasi negara sebagai pelaksana urusan pemerintahan dan pembangunan dengan masyarakat, sering terjadi benturan kepentingan yang melibatkan kedua pihak. Benturan kepentingan ini biasanya diakibatkan oleh adanya keputusan pejabat negara.

Tata Usaha Negara terjadi karena adanya seseorang atau badan hukum perdata yang merasa kepentingannya dirugikan oleh suatu Keputusan Tata Usaha Negara, yaitu suatu penetapan tertulis yang dikeluarkan oleh Badan atau Pejabat Tata Usaha Negara yang berisi tindakan hukum Tata Usaha Negara yang berdasarkan peraturan perundangundangan yang berlaku, yang bersifat konkrit, individual, dan final, yang menimbulkan akibat hukum bagi seseorang atau badan hukum perdata. 2 Gugatan yang diajukan oleh 
seseorang atau badan hukum yang merasa dirugikan tersebut haruslah dengan alasanalasan sesuai yang diatur dalam Pasal 53 ayat (2) Undang-Undang Nomor 5 Tahun 1986 jo Undang-Undang Nomor 9 Tahun 2004 jo Undang-Undang Nomor 51 Tahun 2009 Tentang Peradilan Tata Usaha Negara, yaitu:

Alasan-alasan yang dapat digunakan dalam gugatan sebagaimana dimaksud dalam ayat(1) adalah :

a. Keputusan Tata Usaha Negara yang digugat itu bertentangan dengan peraturan perundang- undangan yang berlaku.

b. Badan atau Pejabat Tata Usaha Negara pada waktu mengeluarkan keputusan sebagaimana dimaksud dalam ayat (1) telah menggunakan wewenangnya untuk tujuan lain dari maksud diberikannya wewenang tersebut.

c. Badan atau Pejabat Tata Usaha Negara pada waktu mengeluarkan atau tidak mengeluarkan keputusan sebagaimana dimaksud dalam ayat (1) setelah mempertimbangkan semua kepentingan yang tersangkut dengan keputsan itu seharusnya tidak sampai pada pengambilan atau tidak pengambilan keputusan tersebut.

Gugatan adalah permohonan yang berisi tuntutan terhadap Badan atau Pejabat Tata Usaha Negara dan diajukan ke Pengadilan untuk mendapatkan putusan. Gugatan terbagi dua yaitu gugatan tertulis dan lisan. Isi tuntutan dan petitum gugatan TUN sudah ditetapkan dalam undang-undang Peradilan TUN, yaitu hanya berisi tuntutan pokok yang bermaksud agar keputusan TUN yang merugikan dirinya dinyatakan batal atau tidak sah. Tidak ada tuntutan pokok lainnya, hanya saja di samping tuntutan pokok dimungkinkan adanya tuntutan tambahan dan juga hanya berupa tuntutan ganti rugi.

Isi tuntutan dan petitum gugatan TUN sudah ditetapkan dalam undang-undang Peradilan TUN, yaitu hanya berisi tuntutan pokok yang bermaksud agar keputusan TUN yang merugikan dirinya dinyatakan batal atau tidak sah. Tidak ada tuntutan pokok lainnya, 
hanya saja di samping tuntutan pokok dimungkinkan adanya tuntutan tambahan dan juga hanya berupa tuntutan ganti rugi. Hal ini lah yang melatar belakangi penulis untuk mengangkat judul "PENGERTIAN GUGATAN DAN BENTUK GUGATAN DAN TUNTUTAN DI PENGADILAN TATA USAHA NEGARA”. Agar pembaca dapat memahami mengenai gugatan dan tuntutan di negara kita ini.

\section{B. PEMBAHASAN}

Menurut pasal 1 angka 11 UU No. 51 Tahun 2009 tentang Peradilan TUN gugatan adalah suatu permohonan yang berisi tuntutan terhadap badan atau pejabat TUN dan diajukan ke pengadilan untuk mendapatkan putusan. Gugatan di Peradilan TUN diajukan oleh seseorang atau badan hukum perdata yang merasa kepentingannya dirugikan akibat dikeluarkannya suatu Keputusan TUN. Adanya unsur kepentingan dalam pengajuan gugatan inilah yang merupakan hal yang sangat urgen dalam sengketa di Peradilan TUN. Hal ini ditegaskan dalam Pasal 53 ayat (1) dimana ketentuan pasal ini menjadi dasar mengenai siapa yang bertindak sebagai subjek penggugat di Peratun, yaitu Orang atau Badan Hukum Perdata yang merasa kepentingannya dirugikan oleh suatu Keputusan TUN. Selanjutnya Pasal 53 ayat menyebutkan alasan-alasan yang dapat digunakan dalam gugatan. Mengenai alasan yang dapat digunakan dalam gugatan, Pasal 53 ayat (2) UU No. 9 Tahun 2004 telah mengubah ketentuan pasal pada UU PTUN sebelumnya, adapun alasan-alasannya sebagai berikut:

a. Keputusan Tata Usaha Negara yang digugat itu bertentangan dengan peraturan perundang-undangan yang berlaku.

b. Keputusan Tata Usaha Negara yang digugat itu bertentangan dengan asas-asas umum pemerintahan yang baik.

Dengan ketentuan penyelesaian sengketa Tata Usaha Negara melalui upaya administrative sebagaiman yang dimaksud dalam pasal 48 ayat (1) dan ayat (2) Undangundang Nomor 5 Tahun 1986, maka dapat diketahui bahwa sengketa Tata Usaha Negara 
yang diselesaikan melalui gugatan adalah sebagai berikut.

a Sengketa Tata Usaha Negara yang penyelesaiannya tidak tersedia upaya administrative, artinya dalam peraturan perundang-undangan yang menjadi dasar dikeluarkannya Keputusan Tata Usaha Negara yang mengakibatkan timbulnya sengketa Tata Usaha Negara tidak ada ketentuan tentang upaya administrative yang harus dilalui.

b. Sengketa Tata Usaha Negara yang penyelesaiannya sudah melelui upaya administrative yang tersedia (keberatan dan atau banding administratif) dan sudah mendapat keputusan dari Badan atau Pejabat Tata Usaha Negara yang mengeluarkan Keputusan Tata Usaha Negara atau atasan atau instansi lain dari Badan atau Pejabat Tata Usaha Negara yang mengeluarkan Keputusan Tata Usaha Negara Tersebut, akan tetapi terhadap keputusan tersebut, orang atau badan hukum perdata yang merasa dirugikan dengan keluarnya Keputusan Tata Usaha Negara masih belum dapat menerimanya.

Dalam Herziene Indonesische Reglement ("HIR") dikenal 2 (dua) macam bentuk surat gugatan yaitu gugatan lisan dan gugatan tertulis. Bentuk gugatan lisan terutama ditujukan bagi mereka yang buta huruf.

\section{Gugatan Tertulis}

Bentuk gugatan tertulis adalah yang paling diutamakan di hadapan pengadilan daripada bentuk lainnya. Gugatan tertulis diatur dalam Pasal 118 ayat (1) HIR / Pasal 142 Rechtsreglement voor de Buitengewesten ("RBg") yang menyatakan bahwa gugatan perdata pada tingkat pertama harus dimasukkan kepada Pengadilan Negeri dengan surat permintaan yang ditandatangani oleh penggugat atau kuasanya. Dengan demikian, yang berhak dan berwenang dalam mengajukan surat gugatan adalah; (i) penggugat dan atau (ii) kuasanya.

2. Gugatan Lisan

Bagi mereka yang buta huruf dibuka kemungkinan untuk mengajukan gugatan secara lisan kepada Ketua Pengadilan Negeri yang berwenang untuk mengadili suatu perkara perdata, karena bentuk gugatan lisan diatur dalam Pasal 120 HIR (Pasal $144 \mathrm{RBg}$ ) yang 
berbunyi: "bilamana penggugat buta huruf maka surat gugatannya dapat dimasukkan dengan lisan kepada Ketua Pengadilan Negeri, yang mencatat gugatan atau menyuruh mencatatnya". Ketentuan gugatan lisan yang diatur HIR ini, selain untuk mengakomodir kepentingan penggugat buta huruf yang jumlahnya masih sangat banyak di Indonesia pada masa pembentukan peraturan ini, juga membantu rakyat kecil yang tidak mampu menunjuk jasa seorang advokat atau kuasa hukum karena dapat memperoleh bantuan dari Ketua Pengadilan yang berwenang untuk mengadili suatu perkara perdata untuk membuatkan gugatan yang diinginkannya.

Pasal 53 ayat (1) Undang-undang Nomor 5 Tahun 1986 jo. Undang-Undang Nomor 9 Tahun 2004 menentukan orang atau badan hukum perdata yang kepentingannya dirugikan oleh suatu Keputusan Tata Usaha Negara dapat mengajukan gugatan tertulis kepada Pengadilan yang berwenang berisi tuntutan agar Keputusan Tata Usaha Negara yang disengketakan itu dinyatakan batal atau tidak sah dengan atau tanpa disertai tuntutan ganti rugi dan/ atau rahabilitasi.

Dari ketentuan yang terdapat dalam Pasal 53 ayat (1) tersebut dapat diketahui bahwa yang dimaksud dengan gugatan dalam penyelesaian sengketa Tata Usaha Negara adalah permohonan secara tertulis dari seseorang atau badan hukum perdata yang merasa kepentingannya dirugikan oleh suatu Keputusan Tata Usaha Negara, yang ditujukan kepada dipengadilan di lingkungan Peradilan Tata Usaha Negara, yang berisi tuntutan agar Keputusan Tata Usaha Negara tersebut dinyatakan batal atau tidak sah dengan atau tanpa disertai tuntutan ganti rugi dan/atau rehabilitasi.

Sebagai permohonan sudah tentu tidak setiap gugatan harus diterima oleh pengadilan di lingkungan Peradilan Tata Usaha Negara, jika syarat-syarat formal dari gugatan belum atau tidak dipenuhi. Jika seandainya gugatan diterima, belum tentu gugatan tersebut harus dikabulkan, karena dikabulkan atau tidak dikabulkannya gugatan, sangat tergantung dari dapat atau tidak dapat dibuktikan gugatan dengan sekurang-kurangnya 2 alat bukti berdasarkan keyakinan hakim. Permohonan dapat diajukan kepada pengadilan Tata Usaha Negara harus merupakan permohonan yang dituangkan dalam bentuk tertulis, sehingga 
merupakan surat gugat, karana surat gugatan ini berfungsi sebagai pegangan bagi pengadilan dan juga para pihak selama pemeriksaan di siding pengadilan. Oleh karena ketentuan tersebut, maka tidak dikenal adanya gugatan tidak tertulis atau gugatan secara lisan.

Dalam penjelasan pasal 53 ayat (1) Undang-Undang No. 5 Tahun 1986 jo. UndangUndang No. 9 Thun 2004, bagi mereka yang tidak pandai baca tulis, dapat mengutarakan keinginannya untuk menggugat kepada panitera yang akan membentu merumuskan gugatannya dalam bentuk tertulis. Dalam hal kompetensi pengadilan, perlu diperhatikan beberapa hal, diantaranya :

1. Perhatikan kekuasaan relative (kompetensi relatif) dari pengadilan sebagaimana yang dimaksud dalam Pasal 54 Undang-Undang No. 5 Tahun 1986. Khusus mengenai apa yang dimaksudkan dalam pasal 54 ayat (3) Undang-Undang No. 5 tahun 1986, perlu kita perhatikan pendapat dari Indroharto[2]. Undang-undang No. 5 Tahun 1986 menerapkan suatu asas hukum acara Tata Usaha Negara yang berupa kewajiban untuk meneruskan gugatan ke pengadilan dilingkungan pengadilan Tata Usaha Negara yang berwenang secara terbatas, sehingga jika terdapat kekeliruan alamat yang lain, hukum acara Tata Usaha Negara tidak mewajibkan untuk mengirimkan gugatannya kepada alamat yang sebenarnya.

2. Penyelesaian sengketa Tata Usaha Negara yang tidak tersedia upaya administratif, gugatan ditujukan kepada pengadilan Tata Usaha Negara, sedag penyelesaian sengketa Tata Usaha Negara yang tersedia upaya administratif, gugatan diajukan kepengadilan sesuai dengan ketentuan Surat Edaran Mahkamah Agung RI Nomor 2 Tahun 1991.

Keputusan Tata Usaha Negara seperti pada perumusan Pasal 53 ayat (1) Undangundang No. 5 Tahun 1986 jo Undang-undang No. 9 tahun 2004 terpasuk juga apa yang dalam literature disebut Keputusan Tata Usaha Berangkai, yaitu keputusan dari Badan atau Pejabat Tata Usaha Negara yang sebelum menjadi keputusan Tata Usaha Negara 
harus didasari atau didahului dengan satu atau beberapa keputusan dari Badan atau Pejabat Tata Usaha Negara.

Dalam menghadapi Keputusan Tata Usaha Negara Berangkai, orang atau badan hukum perdata yang merasa kepentingannya dirugikan, dapat saja mengajukan gugatan kepada pengadilan di lingkungan Peradilan Tata Usaha Negara yang berisi tuntutan agar salah satu keputusan Badan atau pejabat Tata Usaha Negara yang menjadi dasar dikeluarkannya Keputusan Tata Usaha Berangkai dinyatakan tidak sah atau batal dengan atau tanpa tuntutan ganti rugi dan /atau rehabilitasi, asal keputusan dari Badan atau Pejabat Tata Usaha Negara Tersebut merupakan Keputusan Tata Usaha Negara sebagaimana yang dimaksud dalam Pasal 1 angka 3 UU No. 5 Tahun 1986 (Pasal 1 angka 9 UU No.5 Tahun1986 jo. Undang-Undang No. 51 Tahun 2009).

Isi tuntutan dan petitum gugatan TUN sudah ditetapkan dalam undang-undang Peradilan TUN, yaitu hanya berisi tuntutan pokok yang bermaksud agar keputusan TUN yang merugikan dirinya dinyatakan batal atau tidak sah. Tidak ada tuntutan pokok lainnya, hanya saja di samping tuntutan pokok dimungkinkan adanya tuntutan tambahan dan juga hanya berupa tuntutan ganti rugi. Khusus untuk sengketa Kepegawaian diperbolehkan menambah tuntutan / adanya tuntutan tambahan berupa tuntutan rehabilitasi.

Kecuali gugatan TUN harus tertulis, gugatan harus memuat:

1. Nama, kewarganegaraan, tempat tinggal

2. Pekerjaan penggugat atau kuasanya

3. Nama jabatan, dan tempat kedudukan tergugat.

4. Dasar gugatan dalam hal yang diminta untuk diputuskan oleh pengadilan.

Pasal 56 UU PTUN ayat (1) Dalam hal gugatan dibuat dan ditandatangani oleh seorang kuasa penggugat, maka gugatan tersebut harus disertai surat kuasa penggugat, berupa surat kuasa khusus yang sah. 


\section{PENUTUP}

Dari hasil pembahasan yang telah dijelaskan pada bab-bab sebelumnya, dapat diperoleh kesimpulan bahwa gugatan itu merupakan permasalahan perdata yang mengandung sengketa antara 2 (dua) pihak atau lebih yang diajukan kepada Ketua Pengadilan Negeri dimana salah satu pihak sebagai penggugat untuk menggugat pihak lain sebagai tergugat. Gugatan terbagi dalam dua bentuk yaitu gugatan lisan dan tertulis. Dimana gugatan lisan dibuat agar mempermudah seseorang yang buta huruf dalam melaksanakan gugatan. Gugatan lisan merupakan bilamana penggugat buta huruf, maka surat gugatan dapat dimasukkan dengan lisan kepada ketua pengadilan negeri yang mencatat gugatan itu atau menyuruh mencatatnya. Sedangkan gugatan tulisan merupakan gugatan yang diajukan kepada ketua pengadilan negeri yang berkompeten mengadili perkara. Dengan adanya gugatan ini seseorang dapat melakukan tuntutan untuk menangani masalah perdatanya dengan baik yaitu dengan cara menggugat seorang pihak kepada Pengadilan Negeri.

\section{DAFTAR PUSTAKA}

Darmini Roza dan Laurensius Arliman S Peran Pemerintah Daerah Di Dalam Melindungi Hak Anak Di Indonesia, Masalah-Masalah Hukum, Volume 47, Nomor 1, 2018.

Laurensius Arliman S, Komnas HAM dan Perlindungan Anak Pelaku Tindak Pidana, Deepublish, Yogyakarta, 2015.

Laurensius Arliman S, Penguatan Perlindungan Anak Dari Tindakan Human Trafficking Di Daerah Perbatasan Indonesia, Jurnal Selat, Volume 4, Nomor 1, 2016.

Laurensius Arliman S, Problematika Dan Solusi Pemenuhan Perlindungan Hak Anak Sebagai Tersangka Tindak Pidana Di Satlantas Polresta Pariaman, Justicia Islamica, Volume 13, Nomor 2, 2016.

Laurensius Arliman S, Pelaksanaan Perlindungan Anak Yang Tereksploitasi Secara Ekonomi Oleh Pemerintah Kota Padang, Veritas et Justitia, Volume 2, Nomor 1, 2016.

Laurensius Arliman S, Kedudukan Ketetapan MPR Dalam Hierarki Peraturan Perundang Undangan Di Indonesia, Lex Jurnalica, Volume 13, Nomor 3, 2016. 
Laurensius Arliman S, Komnas Perempuan Sebagai State Auxialiary Bodies Dalam Penegakan Ham Perempuan Indonesia, Justicia Islamica, Volume 14, Nomor 2, 2017.

Laurensius Arliman S, Peranan Pers Untuk Mewujudkan Perlindungan Anak Berkelanjutan Di Indonesia, Jurnal Ilmu Hukum Tambun Bungai, Volume 2, Nomor 2, 2017.

Laurensius Arliman S, Mewujudkan Penegakan Hukum Yang Baik Untuk Mewujudkan Indonesia Sebagai Negara Hukum, Jurnal Hukum Doctrinal, Volume 2, Nomor 2, 2017.

Laurensius Arliman S, Participation Non-Governmental Organization In Protecting Child Rights In The Area Of Social Conflict, The 1st Ushuluddin and Islamic Thought International Conference (Usicon), Volume 1, 2017.

Laurensius Arliman S, Partisipasi Masyarakat Dalam Pembentukan Perundang $\bullet$ Undangan Untuk Mewujudkan Negara Kesejahteraan Indonesia, Jurnal Politik Pemerintahan Dharma Praja, Volume 10, Nomor 1, 2017, https://doi.org/10.33701/jppdp.v10i1.379.

Laurensius Arliman S, Peran Komisi Perlindungan Anak Indonesia Untuk Mewujudkan Perlindungan Anak, Jurnal Respublica Volume 17, Nomor 2, 2018.

Laurensius Arliman S, Menjerat Pelaku Penyuruh Pengrusakan Barang Milik Orang Lain Dengan Mempertimbangkan Asas Fungsi Sosial, Jurnal Gagasan Hukum, Volume 1, Nomor 1, 2019.

Laurensius Arliman S, Ilmu Perundang-Undangan Yang Baik Untuk Negara Indonesia, Deepublish, Yogyakarta, 2019.

Laurensius Arliman S, Isdal Veri, Gustiwarni, Elfitrayenti, Ade Sakurawati, Yasri, Pengaruh Karakteristik Individu, Perlindungan Hak Perempuan Terhadap Kualitas Pelayanan Komnas Perempuan Dengan Kompetensi Sumber Daya Manusia Sebagai Variabel Mediasi, Jurnal Menara Ekonomi: Penelitian dan Kajian Ilmiah Bidang Ekonomi, Volume 6, Nomor 2, 2020.

Laurensius Arliman S, Pendidikan Kewarganegaraan, Deepublish, Yogyakarta, 2020.

Laurensius Arliman S, Makna Keuangan Negara Dalam Pasal Pasal 23 E Undang-Undang Dasar 1945, Jurnal Lex Librum, Volume 6, Nomor 2 Juni 2020, http://dx.doi.org/10.46839/1ljih.v6i2.151.

Laurensius Arliman S, Kedudukan Lembaga Negara Independen Di Indonesia Untuk Mencapai Tujuan Negara Hukum, Kertha Semaya Journal Ilmu Hukum, Volume 8, Nomor 7, 2020.

Laurensius Arliman S, Pelaksanaan Assesment Oleh Polres Kepulauan Mentawai Sebagai Bentuk Pelaksanaan Rehabilitasi Bagi Pecandu Dan Korban Penyalahgunaan Narkotika, Jurnal Muhakkamah, Volume 5, Nomor 1, 2020. 
Laurensius Arliman S, Aswandi Aswandi, Firgi Nurdiansyah, Laxmy Defilah, Nova Sari Yudistia, Ni Putu Eka, Viona Putri, Zakia Zakia, Ernita Arief, Prinsip, Mekanisme Dan Bentuk Pelayanan Informasi Kepada Publik Oleh Direktorat Jenderal Pajak, Volume 17, No Nomor, 2020.

Larensius Arliman S, Koordinasi PT. Pegadaian (Persero) Dengan Direktorat Reserse Narkoba Polda Sumbar Dalam Penimbangan Barang Bukti Penyalahgunaan Narkotika, UIR Law Review, Volume 4, Nomor 2, 2020, https://doi.org/10.25299/uirlrev.2020.vol4(1).3779.

Laurensius Arliman S, Tantangan Pendidikan Kewarganegaraan Pada Revolusi 4.0, Ensiklopedia Sosial Review, Volume 2, Nomor 3, 2020.

Muhammad Afif dan Laurensius Arliman S, Protection Of Children's Rights Of The Islamic And Constitutional Law Perspective Of The Republic Of Indonesia, Proceeding: Internasional Conference On Humanity, Law And Sharia (Ichlash), Volume 1, Nomor 2, 2020.

Otong Rosadi danLaurensius Arliman S, Urgensi Pengaturan Badan Pembinaan Idelogi Pancasila Berdasarkan Undang-Undang Sebagai State Auxiliary Bodies yang Merawat Pancasila dalam Perspektif Hak Asasi Manusia, Prosiding Konferensi Nasional Hak Asasi Manusia, Kebudayaan dan Tujuan Pembangunan Berkelanjutan Indonesia pada Masa Pandemi Covid-19: Tantangan untuk Keilmuan Hukum dan Sosial Volume 1, Universitas Pancasila, Jakarta, 2020. 